\title{
Ativismo Homossexual Indígena: Uma Análise Comparativa entre Brasil e América do Norte
}

\author{
Estevão Rafael Fernandes
}

Universidade Federal de Rondônia (UNIR), Porto Velho, RO, Brasil. E-mail: estevaofernandes@gmail.com.

— m 27 de julho de 2008, a repórter Kátia Brasil, da Agência Folha, pu¿ blica uma reportagem intitulada "Índios gays são alvo de preconceito no Amazonas":

Entre os índios ticuna, a etnia mais populosa da Amazônia brasileira, um grupo de jovens não quer mais pintar o pescoço com jenipapo para ter a voz grossa, como a tradição manda fazer na adolescência, nem aceita as regras do casamento tradicional, em que os casais são definidos na infância. Esse pequeno grupo assumiu a homossexualidade e diz sofrer preconceito dentro da aldeia, onde os gays são agredidos e chamados de nomes pejorativos como "meia coisa". Quando andam sozinhos, podem ser alvos de pedras, latas e chacotas. Três ticunas da aldeia Umariaçu 2, na região do Alto Solimões, em Tabatinga (1.105 km de Manaus), contaram para a Folha como é a vida dos homossexuais indígenas na fronteira com a Colômbia e o Peru [...].

Marcenio Ramos Guedes, 24, e seu irmão, Natalício, 22, pintam o cabelo e as unhas e fazem as sobrancelhas. Trabalham como dançarinos em um grupo típico ticuna que se apresenta nas cidades da região.

Marcenio diz que brigava muito com o pai e que saiu de casa aos 15 anos. "Fui para Tabatinga trabalhar como 'empregada doméstica'. Eu fazia comida, passava roupa, lavava." Ao voltar para casa, uma construção de madeira com dois cômodos, onde mora com quatro dos sete irmãos e os pais, Marcenio resolveu cuidar dos afazeres domésticos. O

DADOS - Revista de Ciências Sociais, Rio de Janeiro, vol. 58, n-1, 2015, pp. 257 a 294. 
grupo de dança foi criado em 2007, com apoio da família. “Não sofro discriminação por dançar, todo mundo respeita, assiste. Sofro preconceito [de outros jovens] na aldeia. Se falo alguma coisa, querem me bater, jogar pedra, garrafa."

Natalício diz que tem medo de andar sozinho. "Vou sempre com um colega", afirma [...].

O cientista social e professor bilíngue (português e ticuna) de história Raimundo Leopardo Ferreira afirma que, entre os ticunas, não havia registros anteriores da existência de homossexuais, como se vê hoje.

Ele teme que, devido ao preconceito, aumentem os problemas sociais entre os jovens, como o uso de álcool e cocaína. "Isso [a homossexualidade] é uma coisa que meus avós falavam que não existia", afirmou.

Longe dali, em Sandstone, Minnesota, naquele mesmo ano, ocorreria entre 28 de agosto e 1o de setembro o XX Encontro Intertribal de Representantes Gays, Lésbicas, Bissexuais e Transgêneros de Comunidades Nativas. Ao contrário da realidade ticuna relatada na reportagem acima, as preocupações dos mais de 3.000 representantes de 36 etnias presentes ao encontro eram o centro das atenções. Após a abertura do evento, o então candidato democrata à Presidência, Barack Obama, enviara aos presentes uma mensagem de apoio, à qual Richard LaFortune, representante da instituição que organizava o evento (Two Spirit Press Room), responde: "Nós recebemos bem a expressão de apoio do senador Obama, que certamente não esperávamos. É totalmente apropriado para nossos participantes tribais terem-na ouvido de um candidato à Presidência dos EUA, porque os participantes do encontro representam Nações Soberanas e nós sempre fomos conhecidos como líderes entre nossas culturas".

Notam-se certamente algumas diferenças entre as duas situações aqui retratadas (em Tabatinga e em Sandstone), em termos não apenas da mobilização do movimento indígena em torno de demandas específicas - em especial estratégias de combate a DST/HIV, saúde mental e preconceito, a exemplo do caso norte-americano - como do status que os indígenas homossexuais gozam em suas próprias comunidades. Enquanto aqui os Tikuna (e como veremos adiante, entre os Guarani, Krahó e outros povos indígenas no Brasil) são descritos como percebendo a homossexualidade como algo indigno, os representantes homossexuais indígenas norte-americanos fazem questão de salientar seu papel de "líderes tradicionais em suas culturas". Mais que isso: enquanto no Brasil a homossexualidade indígena é apresentada como 
sendo vista pelos indígenas enquanto "perda cultural", os povos indígenas norte-americanos a teriam em conta, como veremos, de marcador de autodeterminação e estratégia de combate ao discurso colonizador.

Nosso objetivo não será um estudo que busque levantar quais etnias possuem práticas homossexuais, como elas representam essas práticas, ou mesmo um estudo da sexualidade indígena nesta ou naquela etnia. Um trabalho nesse sentido teria que recuperar e examinar as noções hegemônicas sobre o que seria homossexualidade e/ou lançar mão de uma arqueologia da sexualidade, buscando compreender como os povos indígenas interpretariam essas noções. Pesquisas nessa direção trariam contribuições óbvias para o desenvolvimento da Disciplina e ainda estão por ser realizadas no país, certamente sendo enriquecidas pela vasta literatura sobre corporalidade e gênero ameríndios desenvolvidas ao longo das últimas décadas. À exceção de algumas obras e pequenos trechos que mencionam en passant a prática homossexual entre povos indígenas no país - ainda que pululem referências à prática em conversas informais entre etnólogos -, o assunto ainda é, via de regra, pouco trabalhado na antropologia brasileira, no movimento indígena e mesmo no que diz respeito às políticas públicas empreendidas no país. Este trabalho, ainda que aponte algumas direções nesse sentido, não busca preencher totalmente essa lacuna.

A proposta é, ao contrário, buscar recuperar justamente os aspectos que tornaram possível, no contexto norte-americano, o surgimento de uma identidade two-spirit pautada num discurso de tradicionalidade pan-indígena e marcadamente política, enquanto que, no Brasil, a homossexualidade indígena ainda padece de uma cegueira ontológica, tanto por parte dos etnólogos quanto, eventualmente, dos próprios indígenas - questão por si só, interessante. O que se percebe, nesses novos contextos, é a produção de novas formas de convívio e reflexões no campo da alteridade; zonas de interstício (fronteiras) marcadas por serem espaços de redefinições das identidades dos grupos envolvidos nesses processos, os quais não podem ser vistos como meras contingências do contato ou oportunismo por parte de determinados grupos.

Com isso em mente, o trajeto aqui traçado será, em primeiro lugar, situar - ainda que brevemente - o campo de estudos sobre o tema no Brasil. Em seguida, apresentaremos uma revisão da bibliografia disponível sobre o tema nos últimos anos para, então, descrevermos o 
processo de transformações na identidade homossexual indígena na América do Norte, culminando no surgimento do movimento two-spirit. Finalmente, buscaremos apontar algumas considerações e direções que venham a responder por que no Brasil a homossexualidade indígena não alcançou a mesma visibilidade - entre analistas e indígenas - que logrou na América do Norte.

Não coadunamos, por exemplo, com a afirmação de que os indígenas brasileiros seriam algo que, em nossos termos, poderíamos denominar de "homofóbicos". Em primeiro lugar, uma assertiva nesse sentido seria obviamente problemática, por apenas fazer sentido dentro de uma lógica de heteronormatividade coerente com o sistema de valores ocidental. Além disso, a título de exemplo, a descrição que Clastres traz de Krembegi, a ser apresentada na próxima seção, apenas reforça a tese de que práticas homossexuais por si sós não parecem chocar os indígenas. Como escreve Gilley (2010:41), tratando do assunto, se para os indígenas homossexuais a homofobia não é vista como um valor "tradicional", para seus opositores a homossexualidade também não o seria.

Uma discussão retomando as diversas categorias utilizadas para descrever as práticas homossexuais em povos indígenas será feita adiante, mas desde já nos parece importante estabelecermos que, embora sejamos da opinião de que a ausência de um movimento two-spirit aos moldes da América do Norte no Brasil não se deva a uma "homofobia nativa" dos indígenas brasileiros, temos por certo que essa ausência seja reflexo de - e se reflita em - relações de poder específicas estabelecidas não apenas dentro das aldeias mas no âmbito do que denominamos há pouco de "zonas de interstício". Há, supomos, algo que permita que a dinâmica descrita por Gilley possa operar na América do Norte que, caso exista por aqui, escapa aos indígenas e antropólogos.

O argumento que buscar-se-á defender nas páginas seguintes - e sigo aqui o argumento de alguns intelectuais e escritores two-spirit - é o de que a atualização dessa identidade não pode ser compreendida fora do contexto pós-colonial. Assim, para compreendermos a emergência, ou não, de movimentos indígenas homossexuais, faz-se necessário buscar entendê-los não apenas enquanto demandas de gênero ou sobre o corpo mas, sobretudo, como fenômenos políticos relacionados à forma como sua relação com o Estado, com os próprios indígenas e com a sociedade envolvente se mantém. A emergência de movimentos homos- 
sexuais a partir, muitas vezes, de um discurso tradicionalista diz-nos algo sobre relações de poder e políticas de identidade.

As ponderações do ativista cherokee Qwo-Li Driskill vão nesse sentido:

David Eng, Judith Halberstam e Muñoz questionaram: "o que os estudos queer têm a dizer sobre império, globalização, neoliberalismo, soberania e terrorismo? O que os estudos queer nos dizem sobre imigração, cidadania, prisões, bem-estar, luto e direitos humanos?" Enquanto esses movimentos em estudos queer têm criado teorias produtivas, elas não têm se voltado para as complexas realidades coloniais dos povos nativos nos Estados Unidos e Canadá. Buscando responder aos questionamentos postos acima especificamente dentro de contextos nativos, as críticas two-spirit apontam aos estudos queer a responsabilidade de examinar o colonialismo em curso, genocídio, a resistência e sobrevivência das nações e pessoas nativas. Além disso, elas desafiam os estudos queer para complexificar as noções de nacionalismo e diáspora ao prestar atenção às circunstâncias específicas das nações indígenas para as bases territoriais nas quais Estados Unidos e Canadá têm colonizado. Para levar essas questões além, gostaria de perguntar o que as críticas two-spirit podem nos dizer sobre esses mesmos temas. Além disso, o que as críticas two-spirit podem nos dizer sobre nacionalidade, diáspora, colonização e descolonização? O que elas podem nos dizer sobre nacionalismos nativos, tratados de direitos, cidadania e não cidadania? O que elas podem nos dizer sobre internatos, biopirataria, o Allotment Act, o Removal Act, o Relocation Act, e o Indian Act? Como elas podem informar nossa compreensão dos papéis da misoginia, homofobia, transfobia e heterossexualidade na colonização? O que elas têm a nos dizer sobre restauração da linguagem nativa, conhecimento tradicional e sustentabilidade? O que as críticas two-spirit podem nos ensinar sobre sobrevivência, resistência e continuidade? (Driskill, 2010:86-87, tradução livre).

Assim, nosso fio condutor será vislumbrar justamente o que o ativismo homossexual indígena nos permite perceber sobre as relações de poder subsumidas às políticas indigenistas e aos movimentos indígenas. Vejamos.

\section{OLHARES SOBRE HOMOSSEXUALIDADE INDÍGENA NO BRASIL}

É relativamente bem conhecido o capítulo intitulado "O arco e o cesto", em A Sociedade contra o Estado, no qual Pierre Clastres reflete sobre 
Krembegi, um índio Guayaki homossexual. Esse interessante personagem, encontrado por Clastres durante seu período de campo no Paraguai, na década de 1960, era, nos dizeres do autor,

na verdade um sodomita. Ele vivia com as mulheres e, à semelhança delas, mantinha em geral os cabelos nitidamente mais longos que os outros homens, e só executava trabalhos femininos: ele sabia "tecer" e fabricava, com os dentes de animais que os caçadores lhe ofereciam, colares que demonstravam um gosto e disposições artísticos muito melhor expressos do que nas obras das mulheres. Enfim, ele era evidentemente proprietário de um cesto [em contrapartida ao arco, epítome da masculinidade] [...]. Esse pederasta incompreensível vivia como uma mulher e havia adotado as atitudes e comportamentos próprios desse sexo. Ele recusava, por exemplo, tão seguramente o contato de um arco como um caçador o do cesto; ele considerava que seu lugar natural era o mundo das mulheres. Krembegi era homossexual porque era pane [ou seja, tinha azar na caça]. [...] para os próprios Guayaki ele era um kyrypy-meno (ânus-fazer amor) porque era pane. (Clastres, 2003:126)

O autor lhe reservaria ainda um capítulo em outra obra, Crônica dos Índios Guayaki, intitulado "Vida e Morte de um Pederasta", no qual parte do argumento acima fica mais claro:

Homem=caçador=arco; mulher=coleta=cesta: dupla equação cujo rigor regula o curso da vida Aché. Terceiro termo, não há, nenhum terceiro-espaço para abrigar os que não são nem do arco nem da cesta. Cessando de ser caçador, perde-se por isso mesmo a qualidade de homem, vira-se, metaforicamente, uma mulher. Eis o que compreendeu e aceitou Krembegi; sua renúncia radical ao que é incapaz de ser - caçador projeta-o de imediato do lado das mulheres, ele está em casa entre elas, ele se aceita mulher. [...] A lei maior com que se medem todas as sociedades é a proibição do incesto. Krembegi, porque é kyrypy-meno, acha-se no exterior dessa ordem social. Vê-se então cumprir-se até seu termo final a lógica do sistema social ou, o que dá no mesmo, a lógica de sua inversão: os parceiros de Krembegi são seus próprios irmãos. "Picha kybai (subentendido kyrypy-meno) meno-iã: um homem kyrypy-meno não faz amor com seus aliados". Injunção exatamente contrária àquela que rege as relações entre homens e mulheres. A homossexualidade não pode ser senão "incestuosa", o irmão sodomiza o irmão e, nessa metáfora do incesto, confirma-se e reforça-se a certeza de que precisamente o incesto não poderia ser cumprido (o verdadeiro: aquele de um homem e de uma mulher) sem pôr à morte o corpo social. (Clastres, 1995:212-216) 
Interessante notar que, apesar de surgirem na literatura antropológica brasileira algumas referências à figura de Krembegi (como por exemplo Barbosa, 2004; e Stolze Lima, 2011); isso ocorre em autores que buscam discutir aspectos gerais da obra de Clastres, sem que seja dada, na maioria dos casos, uma atenção mais detida ao que postula o autor nos trechos citados acima no tocante especificamente à homossexualidade indígena - o que particularmente causa estranheza, dado o foco na corporalidade e na formação da pessoa ameríndia na antropologia brasileira das últimas décadas.

Aliás, trata-se de dizer claramente que a temática "homossexualidade indígena" não foi tratada mais intensa e extensamente pela etnologia brasileira, na mesma proporção em que se deu o acúmulo de conhecimento (e teorias) sobre povos indígenas no país - ainda que surjam, aqui ou lá, menções a práticas em algumas etnografias, como Gomes (1956), Mélo (1973), a coletânea organizada por Kenneth Kensinger, em 1984; por exemplo. Mais recentemente temos o capítulo escrito por Mott na coletânea intitulada "Sexualidade e saúde indígena", organizada por Ivo Brito, no qual resgatam-se diversas fontes seiscentistas com referências à temática.

Contudo há, na bibliografia disponível sobre a temática, um trabalho que pode representar um bom ponto de partida. Trata-se de texto recentemente publicado na Revista de Antropologia, sobre as "vivências e valores referentes aos relacionamentos homossexuais de pessoas das etnias Guarani Nhandeva, Kaiowá e Terena, na região de Dourados, Mato Grosso do Sul" (Cancela et al., 2010:199). Os autores, após longa discussão sobre seu percurso metodológico, realizam um levantamento da escassa literatura sobre o tema, fazendo referência aos escritos de Mott (que retomarei no parágrafo a seguir), Clastres, já citado aqui, e ao livro de Trevisan (1986) - no qual ele traça algumas considerações sobre práticas homossexuais entre os Krahó. Para Cancela et al., há nessa literatura uma perspectiva de homossexualidade indígena enquanto algo aprendido a partir dos não-indígenas: a homossexualidade seria, portanto, "uma experiência afetivo-sexual anômala advinda do pós-contato, como uma expressão colonialista da economia de corpos e desejos controláveis pelo dominador" (2010:217). A partir daí, os autores trazem os percursos de dois entrevistados, Sebastião e Raimundo, identificados como homossexuais, concluindo seu artigo com a afirmação de que este tema mereça maiores aprofundamentos e pesquisas posteriores. $\mathrm{O}$ texto assim se divide entre o relato da expe- 
riência etnográfica e a história de vida desses dois personagens, sem que haja um maior aprofundamento na análise, em si, das categorias que os próprios autores trazem.

Gostaria, porém, de retroceder no texto de Cancela et al., em particular em sua análise sobre o termo tibira (2010:212ss.). Segundo os autores, Mott associaria esse termo à "presença de 'práticas homossexuais' / 'índios gays' / 'índios homossexuais' entre os indígenas", sendo que entre os Tupinambá os índios gays seriam chamados de tibira e as lésbicas de çacoaimbeguira. A expressão advém de tevi (e suas possíveis variações), palavra que os povos de línguas tupi-guarani da região usam para referir-se às nádegas (Canese e Alcaraz, 2000). Contudo, o excelente trabalho de Chamorro sobre a corporalidade Guarani nos trará novas informações. Escreve a autora que

La homosexualidad masculina es registrada por Montoya como Ava $a k y$, hombre no maduro, que em la jerga castellana equivale a "amujerado". Otra denominación es Ava kuñaeko, “hombre com modos de mujer". Entre los tupinambá, la práctica de la homosexualidad era aparentemente una conducta normal. Los indios-hembra, según el estudio de Ronald Raminelli montaban tiendas públicas para servir como prostitutas. La expresión che atukupe rupi che moangaipa, "pecó conmigo por detrás", puede ser tanto una referencia a la práctica de sexo anal entre heterosexuales u homosexuales masculinos. Ya kuimba'e ojoehe ojomenõ y kuimba'e oñomenõ se refieren al acasalamiento entre varones, traducido por Montoya como "pecado nefando". Tevi, "ano", es otro término en base al cual se denomina la homosexualidad masculina y femenina, como en ava tevíro, "hombre somético", amboteviro, "lo hago un somético", che mbotevi, me torna somético, y kuña tevíro, mujer somética. Curiosamente, Gabriel Soares, entre otros, registró que el término tibira era aplicado a líderes espirituales que siendo hombres "servían de mujer" en los actos sexuales. [...] Según Ronald Raminelli, algunas mujeres "esquivaban contactos carnales con los hombres, viviendo un estricto voto de castidad. Dejaban, por consiguiente, las funciones femeninas y pasaban a imitar a los hombres, ejerciendo los mismos oficios de los guerreros: 'Usan los cabellos cortados de la misma manera que los machos, y van a la guerra con sus arcos y flechas'. Cada hembra guerrera poseía una mujer para servirla, 'con quien dice que está casada, y así se comunican y conversan como marido y mujer'. (Chamorro, 2009: 237-238, ênfases nossas) 
Os trechos negritados acima em nada lembram a descrição que os autores anteriormente citados trazem da homossexualidade entre indígenas no Brasil. Clastres traz Krembegi como síntese do antissistema Guayaki, enquanto Cancela et al. deixam claro, em seu texto, como parte da literatura e dos próprios entrevistados entende essa prática como algo advindo do contato, indo ao encontro da reportagem da Folha de $S$. Paulo, com a qual abrimos este trabalho. Entretanto, o trecho acima traz uma série de referências a uma realidade que simplesmente não aparece na etnologia brasileira, no tocante ao papel espiritual desses indivíduos - ao contrário das inúmeras referências ao tema no contexto norte-americano. É o que veremos a seguir.

\section{HOMOSSEXUALIDADE INDÍGENA NA AMÉRICA DO NORTE}

A literatura acumulada a partir do contexto etnográfico norte-americano pode nos apontar desafios e direções às quais, dada a parca produção acadêmica sobre o tema produzida sobre povos indígenas no Brasil, não temos voltado a devida atenção. Mais que uma vasta produção sobre o tema, o contexto norte-americano revela também vários textos escritos pelos próprios indígenas, como alguns dos que veremos adiante.

No que tange à produção bibliográfica, da década de 1980 até aqui inúmeros livros foram escritos sobre o tema, revelando uma produção relativamente consolidada ao longo dos últimos trinta anos: The Spirit and the Flesh: Sexual Diversity in American Indian Culture foi escrito por Walter Williams, em 1986. Vinte anos depois, o mesmo autor editaria Two-Spirits: A Story of Life with the Navajo, um livro de ficção histórica ambientado na década de 1860. Outro livro-Men as Women, Women as Men: Changing Gender in Native American Cultures, publicado em 1998, escrito por Sabine Lang - explora as diversas atitudes das diferentes culturas indígenas norte-americanas frente aos "homens-mulheres" e "mulheres-homens", à luz das perspectivas de gênero dessas sociedades, incluindo mitologias nativas. A mesma autora virá a participar da edição, juntamente com Sue-Ellen Jacobs e Wesley Thomas do livro Two-Spirit People: Native American Gender Indentity, Sexuality and Spirituality (1997). O livro, que inclui vários de seus 21 capítulos escritos por indígenas autoidentificados como "two-spirit", busca situar os vários aspectos da discussão relacionados ao tema até então, buscando situar conceitos como "berdache", "two-spirit" e homofobia em povos nativos, por exemplo. 
Outro autor que se destaca pela produção sobre o tema é o ativista Will Roscoe. Em 1984 ele é chamado pela organização Gay American Indian para coordenar um projeto intitulado The History Project of Gay American Indians, que culminaria, em 1988, com a publicação do livro Living the Spirit: A Gay American Indian Anthology. O livro é um compêndio de textos (inclusive poemas e pinturas) de indígenas das mais diversas etnias (Sioux, Mohawk, Navajo, entre outros) dividido em duas partes: "Artists, Healers and Providers: The Berdache Heritage" e "Gay American Indians Today: Living the Spirit". Apesar de haver sido escrito antes da adoção do termo two-spirit, o livro já deixa claro, desde seu prefácio (escrito por Randy Burns, indígena Paiute, que funda em 1975 juntamente com Bárbara Cameron, uma Lakota Sioux, a associação Gay American Indian, primeira do gênero nos Estados Unidos), a agenda de lutas do movimento daquele momento para frente:

Indígenas gays e lésbicas eram especiais em várias tribos. Temos raízes aqui na América do Norte. Ao mesmo tempo, os gays nativo-americanos enfrentam uma dupla opressão - tanto racismo quanto homofobia. [...] Como gays, nossas necessidades de saúde não são levadas a sério pelo governo. Como indígenas, percebemos frequentemente que os programas de AIDS negligenciam importantes diferenças culturais e falham em atingir qualquer povo indígena. Muitas agências sequer possuem estatísticas para os índios que atendem, ou nos incluem na categoria "outro/desconhecido". (Roscoe, 1988:2-5; tradução livre; ênfases no original)

Assim, alguns dos principais pontos que viriam a marcar o movimento two-spirit seriam, justamente, a luta contra o racismo e homofobia, a busca por políticas eficazes de combate à AIDS, a articulação de uma rede de movimentos two-spirit e, finalmente, o fortalecimento de uma identidade ligada a um discurso tradicionalista pan-indígena.

É necessário entender, no tocante à AIDS, que até 1990 o Centro de Controle de Doenças (CDC) dos Estados Unidos ainda não tinha uma categoria separada para indígenas, tendo sido criado naquele ano o National Native American Aids Prevention Center (NNAPC) - no site da organização (www.nnaapc.org) há diversos materiais voltados diretamente ao trabalho junto a indígenas two-spirit, como a cartilha Safe and Caring Schools for Two-Spirit Youth: A Guide for Teachers and Students. Mesmo esse material reproduz o discurso de tradicionalidade em torno do two-spirit: 
Ativismo Homossexual Indígena...

Pessoas two-spirit têm uma longa história entre os povos indígenas no Canadá. Antes do primeiro contato com colonizadores Europeus, a maioria dos povos indígenas reconhecia a importância dos indivíduos two-spirit e a responsabilidade especial concedida a eles pelo Criador. Às vezes eram videntes, curandeiros ou líderes em suas comunidades. [...] Apesar disso, o impacto da colonização tem tido longa duração: suprimindo as tradições e papéis two-spirit e deixando gerações de pessoas two-spirit sofrendo de várias formas de discriminação e estigma. (Genovese e Rousell, 2011:2; tradução livre)

Retomando nosso levantamento da literatura two-spirit, é fácil notar como os autores vão gradativamente assumindo a assunção de que a prática seja não apenas tradicional, mas diretamente ligada ao mundo espiritual.

Nesse sentido, em 1991, Will Roscoe publica o livro The Zuni-ManWoman: We'wha and the Zuni third gender role. O livro trata da vida de We'wha, um(a) lhamana (termo traduzido como "3o gênero" ou "two-spirit", pelos pesquisadores) Zuni, que exercia papel de mediador(a) e embaixador(a) dos Zuni. We'wha, como bem descreve Roscoe, foi membro de uma comissão que visitou o presidente norte-americano Grover Cleveland, em 1886, tendo passado seis meses em Washington sem que ninguém, inclusive o presidente, percebesse que aquela índia havia nascido homem. Roscoe defende assim, em seu livro, que os two-spirit não sejam apenas homens travestidos de mulheres (ou vice-versa), mas uma síntese única entre os dois universos, não sendo nem uma coisa, nem outra. Anos depois Roscoe desenvolveria seus argumentos sobre terceiro gênero em seu livro Changing Ones: Third and Fourth Genders in Native North America, publicado em 1998. No livro, Roscoe faz um apanhado de práticas classificadas por ele como berdache (ver sobre isso adiante) em mais de 150 etnias, mas centra seu foco de análise em três estudos de caso: um(a) Crow que lutou na batalha de Rosebud (1876), um(a) Navajo chamado/a Hastiin Klah e uma guerreira Crow com três esposas.

Também na década de 1990 temos a publicação do livro escrito por Richard C. Trexler, intitulado Sex and Conquest: Gender Construction and Political Order at the Time of European Conquest of the Americas (1995). O livro possui uma estrutura e argumentação bastante dissonantes daquela levantada até aqui. Trexler passa em revista, nos seus primeiros capítulos, as práticas homossexuais na Europa mediterrânea à época

DADOS - Revista de Ciências Sociais, Rio de Janeiro, vol. 58, n- 1, 2015 
da "conquista" europeia, bem como as narrativas de cronistas (como Cabeza de Vaca, Lopez de Gomara, entre outros) de práticas sexuais entre os nativos. Contudo, o autor argumenta que a prática do berdache (ver adiante) teria como função servir sexualmente aos homens, de modo a evitar o estupro de mulheres. Dessa forma, os berdaches teriam também papel econômico e político, operando sistemas de trocas entre famílias proporcionando jovens "noivas" temporárias aos homens jovens. O argumento, contudo, não parece ter feito eco entre os pesquisadores - ao contrário, cada vez mais a literatura parece dar voz às reivindicações do movimento two-spirit.

Exemplo disso é o livro editado por Lester B. Brown, intitulado Two Spirit People: American Indian Lesbian Women and Gay Men (1997). A obra se divide em três partes ("Identity", "Social services" e "AIDS and American Indians") que são, de certa forma, resultado das preocupações do movimento two-spirit à época, como mostramos há pouco. O livro peca, contudo, por trazer em certas passagens uma visão bastante genérica e ideologizada das sexualidades indígenas, chegando a afirmar, por exemplo, que os indígenas norte-americanos possuem "crenças muito simples sobre sexualidade humana e tais crenças foram baseadas em suas experiências" (1997:7, tradução livre).

Entretanto, os livros mais recentemente organizados sobre a temática vão em outra direção. Ao longo dos últimos anos, como veremos, surge uma literatura mais madura sobre o tema, da mesma forma que se multiplicam os textos escritos por indígenas two-spirit.

Dentre os livros mais recentes, merece destaque Becoming Two-spirit: Gay Identity and Social Acceptance in Indian Country, escrito por Brian Joseph Gilley (2006). O livro baseia-se em cinco anos de trabalho de campo do autor entre nativos two-spirit e busca responder "por que os homens two-spirit tentam conciliar uma divisão forçada em seus mundos sociais e como eles atingem seu senso de quem são, em meio às ideias contemporâneas de identidade e cultura indígenas" (2006:4, tradução livre). Assim, ao longo de seus sete capítulos, Gilley trata da criação das redes de formação e consolidação do movimento two-spirit frente ao movimento LGBT (majoritariamente formado por brancos) e ao movimento indígena (marcadamente homofóbico). Dessa forma, o autor analisa esse duplo movimento (o qual vai, como vimos, no sentido da "dupla opressão", nos termos de Randy Burns), descrevendo de que forma o movimento two-spirit interage com as comunidades nati- 
vas, confrontando a homofobia e o legado colonial. A narrativa de Gilley, nesse sentido, descreve

como a identidade two-spirit atravessa fronteiras da sexualidade e indianidade, ao contrastar a assimilação de "índios gays" à "responsabilidade tradicional" two-spirit à herança nativa, ou envolvendo-se na "conscientização gay da comunidade" a fim de não incorporar os desejos do movimento LGBT não indígena por diversidade, mas de atrair os gays Nativos para os espaços Nativos (Morgensen, 2008:2078, tradução livre).

De fato, parte considerável da literatura mais recente sobre o tema trata não mais (ou pelo menos não somente) de discutir a terminologia mais adequada para a descrição do fenômeno - boa parte da literatura da década de 1990, produzida no mesmo momento em que se (re)configuravam as redes e identidades two-spirit giravam, como vimos até aqui, em torno dessa questão. O movimento agora vai, justamente, em outro sentido: em se caracterizar a assunção da identidade two-spirit também como um movimento anticolonial. Isso vai ao encontro de nosso argumento, de que não se possa entender o surgimento da identidade two-spirit sem que se compreenda, também, a dinâmica do próprio movimento indígena e das políticas públicas voltadas para esses povos. Dessa forma, a negativa dos indígenas two-spirit ao rótulo de "gays" vai nesse sentido: mais do que o combate à heteronormatividade, há o entendimento de que essa heteronormatividade esteja enquadrada em um discurso e práticas colonialistas - o movimento LGBT, dessa forma, por se construir nesse contexto, não teria condições de representar as demandas indígenas.

Entretanto, como vimos, o movimento two-spirit possui ainda outro desafio: a homofobia indígena. Temos desenvolvido até aqui o argumento de que essa é a principal diferença entre o movimento homossexual indígena brasileiro (ou a falta dele) e o norte-americano. Enquanto aqui o fenômeno é encarado como "vício advindo do contato", lá o movimento two-spirit tenta desconstruir essa visão justamente reafirmando uma tradicionalidade pan-indígena subsumida a essa prática.

Morgensen, em sua análise do livro de Gilley, argumenta nesse sentido, ao afirmar que os two-spirit "também atravessam as fronteiras da indigeneidade - aparência, percentual de sangue, registro - por diversas vezes marcando sua construção ou reforçando seus efeitos marginalizantes, [...] explora[ndo] como o embranquecimento coloca a iden- 


\section{Estevão Rafael Fernandes}

tidade nativa em debate" (2008:2078). Ou seja, mais do que simplesmente operar no âmbito de políticas nativas de gênero, o fenômeno nos diz - e muito - sobre as políticas indígenas de identidade, etnicidade, de construção da tradição e de fronteiras etc. Trata-se de buscar sair da condição de invisível tanto no que diz respeito às demandas dos movimentos indígenas quanto nos LGBT (cf. Gilley, 2006:5-6).

Muito do que foi dito aqui é o argumento de Morgensen, em livro intitulado Space between Us: Queer Settler Colonialism and Indigenous Decolonization (2011). O autor tem dedicado seus estudos à forma como o racismo e o colonialismo estruturaram as políticas LGBT nos Estados Unidos e Canadá. Neste livro, Morgensen trabalha justamente com a relação entre a história colonial, do movimento LGBT e do movimento two-spirit, focando sua análise no ativismo two-spirit enquanto movimento pela descolonização indígena.

Morgensen também participou da organização, em 2011, do livro Queer Indigenous Studies: Critical Interventions in Theory, Politics and Literature, juntamente com Brian Joseph Gilley, Qwo-Li Driskill (two-spirit cherokee) e Chris Finley (membro do Colville Confederated Tribes, Washington). O livro, em suas primeiras páginas, aponta uma série de questões as quais buscará responder:

Como uma geração anterior de estudos antropológicos e gays e lésbicos definiam o conhecimento acadêmico sobre gênero, sexualidade e povos indígenas? Como antigas descrições foram substituídas por décadas de organização e escrita indígena LGBTQ2 [Gays, Lésbicas, Bissexuais, Travestis, Transgêneros, Transexuais, Queer e Two-Spirit]? Como nós compreendemos as culturas e políticas que os indígenas LGBTQ2 criam, incluindo a reivindicação de identidades como fa'afafine, asegi, e takatapui? Como a atual teoria em estudos queer e indígenas informam nosso trabalho, da promoção da teoria queer de uma "crítica sem sujeito", aos esforços dos estudos indígenas em centralizar os conhecimentos indígenas e investigar criticamente o colonialismo? (Driskill et al., 2011a:2, tradução livre)

Os autores buscarão, assim, ao longo dos doze capítulos que compõem o livro, responder a essas questões, unindo two-spirit critiques e queer indigenous critiques (ibidem:22), por entenderem que ambas se complementem: o queer na crítica à heteronormatividade, o two-spirit enquanto crítica ao projeto colonial. 
Na verdade, a opção por trazer aos estudos two-spirit à teoria queer contém, em si mesma, uma crítica aos usos acadêmicos do termo two-spirit - em especial após a publicação de Two-Spirit People, em 1997, sobre o qual já tratamos. Driskill et al. (2011:13ss) criticam o livro de Jacobs, Thomas e Lang, por ele não refletir a mudança nos métodos de produção de conhecimento nos estudos nativos, bem como pelo fato de que vários colaboradores do livro organizado por Jacobs, Thomas e Lang. haverem simplesmente substituído o termo berdache (como veremos, isso seria algo equivalente a "pederasta" ou "sodomita") por two-spirit, como se fossem equivalentes. Além disso, Driskill e os demais criticam o fato de que, naquele livro, Jacobs e seus colaboradores teriam deixado em segundo plano as contribuições dos autores indígenas, dando especial atenção aos colaboradores acadêmicos - reproduzindo, assim, a lógica de dominação.

Dessa maneira, vários estudiosos do assunto que teriam tomado o livro de Jacobs, Thomas e Lang como referência acabaram colocando o uso do termo two-spirit em xeque, sem perceber que isso ia diretamente de encontro às demandas dos ativistas two-spirit que buscavam, justamente, um termo que agregasse uma identidade pan-indígena, mais do que - como queriam os antropólogos - acentuasse especificidades locais e/ou culturais. Dessa forma, à medida que o ativismo two-spirit se distanciava da academia, se aproximava da literatura e das teorias queer, justamente pelo fato de que a

teoria queer não é um quadro de referência singular, conceitual ou sistemático, mas sim uma coleção de compromissos intelectuais com as relações entre sexo, gênero e desejo sexual. Se a teoria queer é uma escola de pensamento, então ela é uma escola com uma visão bastante heterodoxa de disciplina. O termo descreve um leque bastante diverso de práticas e prioridades críticas: leituras da representação do desejo pelo mesmo sexo em textos literários, filmes, música e imagens; análise das relações de poder sociais e políticas da sexualidade; críticas do sistema sexo-gênero; estudos de identificação transexual e transgênero, de sadomasoquismo e de desejos transgressivos. (Spargo, 2006:8-9)

Assim, a opção pela teoria queer no lugar da antropologia reflete um desejo - e possivelmente a necessidade - de se obter maior visibilidade da (e na) própria produção two-spirit, inclusive artística.

Isso nos ajuda a entender por que esse livro foi lançado em conjunto com aquele organizado por Driskill, Daniel Health Justice (Cherokee),

DADOS - Revista de Ciências Sociais, Rio de Janeiro, vol. 58, nº 1, 2015 
Deborah Miranda (two-spirit da nação Ohlone/Costonoan-Esselen) e Lisa Tatonetti (2011b), intitulado Sovereign Erotics: A Collection of Two-Spirit Literature. O livro pretende dar continuidade aos propósitos de Living the spirit, consistindo basicamente numa coletânea de textos de autores two-spirit. À medida que esses autores vão se aproximando da teoria queer e se distanciando do debate antropológico sobre a questão, é notável como gradativamente os textos sobre o tema passam a figurar em coletâneas organizadas por indígenas e/ou pesquisadores da área de literatura. Exemplo disso é o número do periódico GLQ: A Journal of Lesbian and Gay Studies intitulado "Sexuality, Nationality, Indigeneity: Rethinking the State at the Intersection of Native American and Queer Studies", organizado em 2010 por Daniel Health Justice (um dos organizadores da obra anterior), em conjunto com Bethany Schneider e Mark Rifkin. Apesar de alguns artigos tratarem de heteronormatividade e colonialismo em uma perspectiva histórica, parte considerável do volume é composto por histórias de vida e análises de obras literárias e filmes, partindo da teoria queer.

Além dessas obras, mais uma reforça a recente aproximação dos estudos two-spirit com a teoria queer (até aqui, foram pelo menos quatro obras nos últimos dois anos, como vimos): o livro de Mark Rifkin intitulado When did Indians become Straight? Kinship, the History, and Native Sovereignty. Como o autor relata, seu livro

demonstra como o imperialismo americano contra os povos nativos ao
longo dos últimos dois séculos pode ser compreendido como uma for-
ma de torná-los "hetero" [straight, no original, cujo significado é tanto
de "heterossexual" quanto "em ordem", "correto", "direito"]-ao inse-
rir os povos indígenas em noções anglo-americanas de família, lar, de-
sejo e identidade pessoal. (Rifkin, 2011:9, tradução livre)

Como vemos, até aqui, mais uma vez surge a questão das identidades indígenas fora do esquema heteronormativo colonial como uma forma de resistência política. Contudo, Rifkin oferece-nos em seguida uma explicação de por que o foco dos estudos sobre a temática se voltou, gradativamente, para as obras artísticas desses indígenas, a partir da teoria queer: "Seus trabalhos enfatizam o papel desempenhado pela 'sexualidade' nativa em formas tradicionais de identificação política e tomada de posição enquanto também localizam a violência em curso nos EUA em suas tentativas de traduzir a vida social nativa em termos euro-americanos" (2011:9) 
Dessa forma, o autor trata em seu livro dos textos escritos por nativos a respeito das mudanças na política indigenista nos Estados Unidos entre os séculos XIX e início do XX, comparando-os com os textos de autores queer contemporâneos - nativos ou não. No percurso, alguns conceitos como soberania, heteronormatividade, parentesco e raça serão desenvolvidos a partir das teorias queer. Como Gilley irá notar, a análise de Rifkin demonstra a "intrusão capilar de ideias assentadas nos conceitos fundamentais sobre os quais muitas atividades a nível nacional baseiam suas reivindicações por soberania. Dessa forma, o autor nos lembra que a soberania é um conceito seletivo, excludente e hétero" (Gilley, 2012:572; tradução livre). A questão, dessa forma, passa a ser novamente (ainda que não necessariamente à luz da Antropologia) a relação política mantida entre o Estado - desde sua formação até os dias de hoje - e os povos indígenas, bem como a própria trajetória que tornou possível a formação de uma identidade two-spirit vis-à-vis a própria trajetória do movimento indígena.

Trata-se, como vimos, de algo mais além da assunção de uma identidade individual pautada em hábitos sexuais, mas de uma demanda anticolonial pautada em um discurso tradicional pan-indígena. O que os vários escritos aqui trazidos nos permitem perceber é que o eixo de discussões se desloca do conceito de two-spirit em si (em princípio visto apenas como uma alternativa politicamente correta para berdache) para a expressão dessa identidade, já assumida e ostentada. Nesse sentido trataremos de, na próxima seção, expor brevemente os caminhos que foram trilhados até chegar-se ao two-spirit para depois retornarmos com algumas considerações em face ao que foi exposto até o momento.

\section{DE MUREJADO A TWO-SPIRIT: EMERGÊNCIA DE UMA IDENTIDADE}

Nesta seção apresentaremos brevemente alguns dos termos até aqui utilizados - como two-spirit e berdache, por exemplo - e de que maneira as mudanças de terminologia corresponderam, quase sempre, a uma mudança na perspectiva das práticas homossexuais indígenas na América do Norte cada vez mais próxima de uma crítica ao colonialismo. Dessa maneira, em um primeiro momento temos termos como $\mathrm{mu}$ jerado e joyas, passando a berdache, gay, terceiro gênero e, finalmente, two-spirit. Deixo claro desde já que os termos não são, de forma alguma, sinônimos entre si: sua compreensão passa necessariamente pela compreensão do momento pelo qual os povos indígenas passavam 
frente ao agente colonial e, mais à frente, em relação aos movimentos LGBT e indígena.

Com esse intuito tomaremos como ponto de partida o artigo de Roscoe publicado no $G L Q$ em $1995^{1}$. Nele, o autor parte de uma pergunta aparentemente simples, feita por um índio Zuni quando o autor passava pelo Novo México. Sabendo que Roscoe alguns anos antes havia publicado o livro sobre We'wha, Alex Seotewa, liderança Zuni, lhe pergunta: "Você acha que We'wha era homossexual"? O questionamento serve como desencadeador da análise, feita por Roscoe, sobre até que ponto a expressão "homossexualismo" se adequa à descrição do que era We'wha, por exemplo. Mais que isso, a esta segue-se, inevitavelmente, outra pergunta: os indígenas homossexuais hoje podem evocar uma identidade two-spirit? A questão é, por si só, complexa e depende de desnaturalizar a própria noção de homossexualidade como compreendida no ocidente, enquanto categoria que somente viria a surgir no século XIX, como bem demonstra Foucault em seu primeiro volume de História da Sexualidade.

Se nosso próprio conceito de homossexualismo não é unívoco, por que as práticas dos povos indígenas, compreendidas por nós, hoje, como "homossexuais", seriam? Roscoe fará assim um levantamento da vasta literatura de cronistas com referências ao tema - nesse sentido, recuperar os escritos de Luiz Mott no contexto brasileiro poderia ser bastante interessante, em um estudo comparativo - a fim de mostrar como o uso de diversas categorias em variados momentos da colonização norte-americana revela uma heterogeneidade nas práticas levadas a cabo pelos agentes coloniais.

Da mesma forma, os povos indígenas também demonstram dinamismo na forma como classificam, eles mesmos, as práticas homossexuais. Um exemplo disso é dado por Roscoe, a partir de sua própria experiência, ao afirmar (1995:198) que em 1987 a expressão Zuni lha'ma ou lhamana ainda era utilizada para referir-se a pessoas como $\mathrm{We}^{\prime} \mathrm{Wha}$, enquanto um novo termo - lhalha - era utilizado para referir-se a homossexuais. Anos depois, em 1993, o autor soube que ' $e$ 'tsawak'i (garota-garoto) era usado para referir-se aos two-spirit tradicionais, enquanto lha' ma passou a ser utilizado para designar "gay". O autor sintetiza seu argumento da seguinte forma:

De fato, uma revisão da extensa literatura de contato - relatos de exploradores europeus, comerciantes, missionários e assim por diante - su- 
Ativismo Homossexual Indígena...

gere que os intercâmbios culturais entre os conceitos nativos e branco de sexualidade seguiram conforme os modelos de Sahlins previam. Os papéis two-spirit eram tanto reproduzidos quanto transformados. No que se segue, virei esboçar essa "conjuntura da estrutura" em dois cenários distintos: na fronteira norte-americana, onde europeus e two-spirits se encontraram cara-a-cara; e na Europa, onde aqueles que liam os relatos sobre two-spirits criaram um vasto discurso sobre eles que eventualmente contribuiu para os discursos médicos e políticos sobre homossexualidade no final do século XIX. (Roscoe, 1995:197, tradução livre, negrito nosso, itálico no original)

Neste ponto, uma coisa chama a atenção: o fato de que em diversos relatos os two-spirits descritos mantêm o papel de mediadores. A noção, na etnologia brasileira, não é tão estranha assim. Remeto aqui à clássica análise de Roberto DaMatta sobre o mito timbira de Auké, e à sua assunção de que, nos mitos, os jovens e as mulheres exerçam, note-se, papel de mediadores: "a categoria mulher parece ficar situada numa área onde é possível a sua conexão com o plano da natureza. A categoria mulher, portanto, estaria situada entre homens e animais, donde sua ambiguidade, isto é, sua capacidade de, em certas circunstâncias, organizar ou desorganizar relações sociais" (DaMatta, 1970:94).

Deixo o trecho acima a título de provocação para pesquisadores interessados em investigar de que forma a homossexualidade indígena pode se articular com as perspectivas indígenas de gênero à luz de suas cosmologias, noções de pessoa, corpo, parentesco etc. É possível que o homossexual (ou, pelo menos, o homossexual masculino) acabe incorporando a ambiguidade feminina ou, por outro lado, que seja, ele mesmo, um elemento ambíguo.

Alguns textos citados anteriormente sobre Krembegi deram já alguns passos nessa direção, mas, para os fins deste trabalho, especificamente, nos interessam as eventuais consequências desse papel de mediador assumido pelo two-spirit no que diz respeito às relações interétnicas. Lembremos, novamente, do que diz LaFortune respondendo a Barack Obama, no encontro em Tombstone: "nós sempre fomos conhecidos como líderes entre nossas culturas". O papel, justamente, que figuras como We'wha (Zuni, 1850-1896) e Hastín Klah (Navajo, 1867-1937) desempenham reforça nosso argumento de que a compreensão da assunção da identidade two-spirit passa, necessariamente, pela compreensão das políticas interétnicas - por isso, voltemos a Roscoe. 
O autor dedica boa parte de seu artigo (1995:201ss) a fazer uma exegese dos termos utilizados por cronistas e autores diversos (padres, comerciantes, aventureiros etc.) para referirem-se à homossexualidade indígena, por entender que esses termos deem pistas sobre a influência das categorias nativas e europeias umas sobre as outras. Ele destaca num primeiro momento que esses termos são quase sempre derivados da palavra francesa berdache, da espanhola mujer, do inglês hermaphrodite e da palavra de origem nativa, joya. Vejamos o que ele nos diz sobre cada uma dessas categorias.

Berdache (e suas variações, como la berdach, berdash, bundosh, broadash etc.) seria utilizado desde o século XVII, tendo sido adotado por vários antropólogos, como vimos, para referir-se à prática. $\mathrm{O}$ termo provém do persa para prisioneiro ou escravo jovem, sendo incorporado por diversas línguas europeias vindo a significar o parceiro mais jovem em uma relação homossexual com acentuada diferença de idade. Aos poucos o termo caiu em desuso na Europa, continuando a ser utilizado nas colônias e, com a etimologia da expressão se perdendo, os estudiosos seguiram utilizando-o.

Já a expressão mujerado, bem como suas variações (hombres mugeriegos, amejerado, mojara, mujerero etc.), pode ser traduzida como "afeminado", sendo utilizada principalmente entre os séculos XVII e XVIII, chegando contudo até o século XX. Outro termo ao qual nos apresenta Roscoe é joya, utilizado entre o final do século XVIII e início do XIX, relacionado etimologicamente a povos nativos da Califórnia Central. Como o autor aponta, apesar dessa expressão ser tributária de um termo nativo, ainda assim é possível perceber em seu uso relações de poder. Segundo ele (ibidem, 203), em censos promovidos por órgãos oficiais ou missões, o termo joya aparecia ao lado de homens que realizavam ações usualmente femininas, como a confecção de potes, por exemplo. Nesse caso, seus nomes eram algo como "Juan Amujerado", refletindo justamente a perspectiva europeia de configurar os two-spirits como desviantes, marginais - o mesmo se pode dizer quando do uso da expressão hermaphrodite e suas variações, utilizadas entre os séculos XIX e XX, sendo já reflexo de uma perspectiva classificatória pautada em termos médicos, como veremos adiante.

Relevante, para os fins deste trabalho, é a pergunta feita por Roscoe nesse momento de seu texto: "Qual foi o impacto desses termos nos conceitos de sexualidade e gênero mantidos pelos nativos e europeus 
que deles se utilizavam?" (ibidem:204). Um dos efeitos, sustenta o autor, seria a percepção de que cada um desses casos de variação de gênero seria parte de um problema "indígena" genérico, mas apenas característico deste ou daquele grupo. Isso criou uma situação interessante:

Quando os nativos começaram a se comunicar com os europeus, muitos deles já tinham um conceito pan-tribal da condição de terceiro gênero. De fato, a assunção de que os papéis de terceiro gênero era um fenômeno universal levou alguns nativos a buscar - e encontrar - tais papéis em pessoas do mundo branco. Na década de 1930, os velhos Navajo comentaram com o antropólogo Willard Hill, "deve haver muito mais travestis [nádleehé] entre os brancos que entre os Navajo porque tantas mulheres brancas usam calças" (ibidem:205, tradução livre, ênfase nossa).

Entretanto, não foram apenas os indígenas que gradativamente tomavam consciência da prática enquanto fenômeno, pela disseminação desses termos genéricos: o discurso europeu também. Dessa forma, em um primeiro momento o discurso europeu produziu descrições pautadas em uma perspectiva moral da diversidade cultural (a prática, condenada pela Igreja, era vista como clara prova da inferioridade dos nativos); em seguida, da monstruosidade (a partir do uso de categorias como hermafroditismo e sodomia); um discurso histórico-filosófico; e, no século XIX, a partir das Ciências Sociais e da Medicina - com autores como Cornelius de Pauw, por exemplo, questionando sobre as eventuais causas do hermafroditismo em nativos americanos (Roscoe, 212ss). Dessa forma, Roscoe consegue fazer de forma bastante convincente uma exegese dos diversos autores - e seus usos - que se debruçaram sobre a problemática, traçando um roteiro detalhado desde as descrições do século XVI até as mais recentes, demonstrando como essas perspectivas, polívocas de ambos os lados, entrecortam-se continuamente. Como aponta o autor, "não há papel two-spirit 'puro' nem categoria ocidental 'pura' de homossexualidade; após cinco séculos de contato, uma se refere à outra" (ibidem:217).

As diversas categorias em jogo - berdache, gay, mujerado etc. - são produtos híbridos de um processo histórico, frutos de interações em uma zona de fronteira com símbolos e identidades sendo constantemente ressignificados e renegociados. Exemplo claro disso é, justamente, a assunção da identidade two-spirit por indígenas norte-americanos a partir, principalmente, de 1990.

Naquele ano, por ocasião da Third Native American/First Nations Gay and Lesbian Conference, em Winnipeg, estudiosos, indígenas e

DADOS - Revista de Ciências Sociais, Rio de Janeiro, vol. 58, nº 1, 2015 
ativistas resolveram substituir o termo berdache por two-spirit - preferência ratificada quando da realização pela American Anthropological Association, em 1993, da conferência Revisiting the North American Berdache, Empirically and Theoretically. Contudo, a escolha pela expressão two-spirit, proveniente da expressão ojibwa niizh manitoag possui implicações-chave para a investigação a que me proponho.

Como escrevem Jacobs et al.,

A decisão pelos nativos americanos (indígenas dos Estados Unidos) e daqueles das Primeiras Nações (povos indígenas do Canadá) que participaram da conferência de Winnipeg e da seguinte em usar a identidade two-spirit foi deliberada, com uma clara intenção de se distanciar dos não indígenas gays e lésbicas. Parece-nos uma coincidência interessante que esse distanciamento marcado tenha acontecido num momento em que os governos dos Estados Unidos e Canadá estavam apenas começando a responder à epidemia da AIDS na comunidade gay. Muitos homens nativo-americanos urbanos tentaram voltar para casa em suas reservas para passar seus últimos anos com suas famílias antes de morrer por complicações da infecção pelo HIV. Cada um de nós ouviu histórias pessoais de homens que não eram bem-vindos em "casa" porque eles tinham "doença de gay branco" e que homossexualidade não era parte da cultura tradicional. Usando a palavra two-spirit, enfatiza-se o aspecto espiritual da vida e minimiza-se a persona homossexual (1997:3, tradução livre).

A fim de entender esse movimento parece importante situarmos que tipo de articulação tornou possível, dentro do movimento homossexual indígena norte-americano, sua própria existência.

Roscoe (1998:100ss) traça um panorama dos caminhos que levaram a essa articulação - advinda tanto das lutas pelos direitos homossexuais em San Francisco (Califórnia) quanto das lutas indígenas na América do Norte, bem como, posteriormente, pelas demandas surgidas com o aparecimento da AIDS. Roscoe situa como marco dessa luta justamente a fundação, como apontamos anteriormente, da GAI (Gay American Indian), em 1975. Segundo os índios por ele ouvidos ao longo de seu trabalho, a articulação que levou à criação dessa organização apenas foi possível após a ocupação de Alcatraz por ativistas indígenas, em novembro de 1969: o movimento Red Power deu aos grupos indígenas inclusive aqueles marginalizados, como os homossexuais - coragem para organizarem-se e enfrentarem o aparato pós-colonial. Até então, 
os indígenas homossexuais eram vistos como párias, mesmo pelos indígenas; e como resultado da ação colonial (que incluía práticas como conversão forçada, integracionismo sexual, corte de seus cabelos como forma de humilhação e, eventualmente, assassinatos). O discurso que então as lideranças indígenas proferiam era, majoritariamente, no sentido de que a homossexualidade refletia todas as atitudes encaradas pelo discurso heteronormativo ocidental de que a homossexualidade corresponderia à depravação. O que o editor da revista indígena Akwesasne Notes escreve ao jornal gay RFD em larga medida lembra a reportagem com a qual abrimos este artigo: “Não queremos receber suas publicações, pois elas encorajam um tipo de comportamento o qual nossos anciãos não consideram normal e é uma decadência de nossa forma de vida" (Roscoe, 1998, 102).

Assim, como Roscoe descreve nas páginas seguintes, entre as décadas de 1970 e início de 1980 a GAI cresceu em número de participantes sendo, no entanto, até 1985, a única associação do gênero na América do Norte. Contudo, em 1987, um dos fundadores do grupo foi diagnosticado com AIDS, sendo o primeiro filiado a receber o diagnóstico. A comunidade indígena homossexual tomara consciência de que a doença não era restrita aos não indígenas, sendo que a GAI funda o Indians AIDS Project, em 1988, para atendimento dos indígenas na região de San Francisco. Da mesma forma, é criada em 1987 a American Indian Gays and Lesbians (AIGL) em Minneapolis, com vistas a criar uma infraestrutura, baseada nos valores tradicionais, aos nativos gays, chegando a representar membros de até 30 diferentes etnias. Mais tarde o grupo participaria da formação do Minnessota American Indian AIDS Task Force, do National Indian AIDS Media Consortium, entre outros. Outra organização, fundada em Toronto em 1989 (a Gays and Lesbians of the First Nations) também viria a trabalhar com assuntos relacionados a HIV / AIDS, vindo a ter, em 1992, mais de 300 membros ativos de 16 povos Inuit e indígenas, vindo inclusive a patrocinar o Two Spirits Softball Team. Também em 1989 foi fundado o WeWah and BarCheeAmpe na cidade de Nova Iorque, também voltado para assuntos relacionados à AIDS, participando da implantação do projeto American Indian Community House, em 1990, e, em 1991, sediando a Two spirits and HIV: A Conference for the Health of Gay and Lesbian Native Americans (Roscoe, 1998:103). O autor aponta ainda outras organizações fundadas nesse período: a Nichiwakan, em Winnipeg; a Tahoma Two Spirits, em Seattle; a Vancouver Two-Spirits; e a Nations of the Four Directions, em San Diego, além de outras em Washington DC e Nashville. 
Uma das dificuldades encontradas por estas organizações, já mencionada aqui, foi a completa falta de dados concernentes à AIDS entre indígenas, o que somente viria a mudar com a criação do National Native American AIDS Prevention Center, citado aqui. Em 1997 havia 1.677 casos oficiais de índios infectados com AIDS nos Estados Unidos - a título de comparação, havia no Brasil em 2001, conforme dados da Fundação Nacional de Saúde (Funasa), 50 indígenas com diagnóstico confirmado de AIDS (Brito, 2011).

Contudo, como resultado indireto desse percurso, Roscoe (1998:107-108) sinaliza que a luta contra a AIDS significou também a luta contra a homofobia, tornando possível que vários indígenas homossexuais despontassem como lideranças, bem como vários índios diagnosticados com a doença retornaram às suas comunidades. Mais que isso: crescia também a consciência de tradições de gêneros alternativos, não apenas pela memória oral, mas livros que buscavam retratar essas realidades - como Living the Spirit e The Spirit and the Flesh, ambos tratados aqui. Assim, as organizações homossexuais indígenas começaram a ter como bandeira de luta recuperar o papel "tradicionalmente sagrado" dos two-spirits em suas culturas (1998:108-109).

Em 1988 a AIGL organiza o The Basket and the Bow: A gathering of Lesbian and Gay Native Americans, em Minneapolis - chamo a atenção para o nome do encontro, se comparado ao clássico capítulo escrito por Clastres sobre o assunto. O encontro daria origem aos encontros internacionais que ocorrem anualmente, reunindo two-spirits do Canadá e Estados Unidos. Todos esses acontecimentos levaram a uma redescoberta das práticas então descritas como berdache, sendo que, por motivos já expostos aqui, o movimento resolve abraçar o termo two-spirit, com organizações como a Gays and Lesbians First Nations, de Toronto, mudando seu nome para 2-Spirited People of the 1st Nations.

Nas palavras de Sue Beaver (Mohawk):

Acreditamos que existam interiormente espíritos tanto de homens quanto de mulheres. Nós nos achamos muito privilegiados. O Criador fez seres muito especiais ao criar os two-spirits. Ele deu a certos indivíduos dois espíritos. Somos pessoas especiais, e isso foi negado desde o contato com os europeus (...). O que os heterossexuais obtêm no casamento, nós alcançamos dentro de nós mesmos. (Roscoe, 1998:109, tradução livre) 
Na verdade, mais do que a adoção de termos como gay, gênero alternativo, berdache etc., o termo two-spirit recuperava um papel tradicional e, mais que isso, sagrado - diferentemente dos demais termos. Além disso, ao fazê-lo, tomava-se uma postura anticolonial, por não mais aceitar as categorias ocidentais de classificação de determinadas práticas: a identidade two-spirit assim tornava-se símbolo de uma identidade pan-indígena.

\section{CONSIDERAÇÕES FINAIS}

Recuperemos até aqui alguns dos pontos levantados. Inicialmente, temos um fenômeno que ao longo da história colonial sempre foi reprimido e invisibilizado: as práticas homossexuais indígenas em suas mais diversas formas. Contudo, como também pudemos perceber, mais que isso, tais práticas devem ser compreendidas enquanto processos, sendo que ao longo dos últimos séculos as diversas perspectivas sobre essas práticas foram se modificando, na medida em que se transformavam e se rearticulavam (internamente, inclusive) conceitos como indianidade, identidade, masculinidade, feminilidade, autenticidade, entre outros. Temos, também, visões diversas entre analistas sobre o tema, que oscilam entre a visão particularista - como parte dos textos escritos por antropólogos trazidos aqui, os quais defendem que essas práticas somente podem ser compreendidas dentro das lógicas culturais nas quais se inserem - até teóricos queer e ativistas, que a apresentam como identidade comum a diversos povos, fortalecendo uma identidade pan-indígena e transformando sua visibilidade em demanda anticolonial.

O que percebemos foi, ao mesmo tempo, a existência de diversas perspectivas dos próprios indígenas sobre o assunto, também oscilando entre a visão de que tais práticas sejam fruto do contato com a sociedade não indígena, bem como aqueles que, ao contrário, veem sua invisibilidade como fruto desse contato. De certa forma, isso diz respeito às estratégias dos próprios movimentos indígenas frente às reinterpretações de sua identidade e ao próprio capital simbólico utilizado por eles enquanto instrumento de luta. A existência de um movimento homossexual indígena, por exemplo, aos moldes apontados até aqui certamente vai de encontro às perspectivas que colocam os indígenas como artefatos do passado, a-históricos, da mesma forma que, dito de forma simples, também não se enquadra nos estereótipos utilizados pelos

DADOS - Revista de Ciências Sociais, Rio de Janeiro, vol. 58, nº 1, 2015 
próprios movimentos indígenas visibilizarem suas demandas - como de indígenas enquanto guerreiros, por exemplo.

Ora, até aqui nosso percurso parece levar à conclusão de que o surgimento de uma identidade two-spirit faça sentido enquanto uma das possíveis "estratégias políticas surgidas em situações coloniais de extrema complexidade e diversidade, e na qual os atores sociais indígenas estão engajados em relações de poder desmedidamente assimétricas" (Baines, 1997:68). Nesse sentido, o autor lança mão de um conceito, ao nosso ver, chave: o de etnogênese.

Da mesma forma, Repetto, que define movimentos indígenas em Roraima como algo surgindo em resposta aos diversos atores sociais por ele analisados, caracterizando-se como movimentos que "questiona[m] o sistema histórico de dominação" (2008:106). Isso remete ao que foi adiantado de nosso argumento, de que movimentos indígenas homossexuais são fruto de uma demanda coletiva que diz respeito a relações de poder. Mais que isso, cabe aqui fazer uma ponte com um conceito de etnogênese, ao qual chamamos a atenção acima.

A respeito desse conceito, escreve Baines que ele remeteria

a processos de reconstrução étnica, mesmo que esse processo não seja verbalizado em termos de uma identidade "indígena", em situações de contato inter-étnico marcadas pelo lugar subordinado vivenciado por essas populações frente ao Estado-nação. [...] Aqui vale ressaltar que uso o conceito de invenção social da tradição não no sentido de inautenticidade, mas no sentido de um processo dinâmico e criativo (Wagner, 1981). [...] As tradições reinventadas representam uma resposta criativa a contextos coloniais. (1997:68-69, ênfases nossas)

Dessa forma, mais que uma "simples" reconfiguração de grupos étnicos [re]pensados a partir de uma herança comum amparada por um eventual vínculo histórico ou genealógico com alguma sociedade précolombiana, a etnogênese enquanto assunção por um coletivo de uma diferença é, antes de tudo, um ato político. Tal qual escreve Repetto (2008), esses coletivos [re]inventados buscam questionar determinado sistema histórico de dominação. Diversos autores parecem corroborar esse ponto de vista.

Hill, por exemplo, escreve que o termo "não é apenas um rótulo para a emergência histórica de povos culturalmente distintos, mas um conceito abrangendo as lutas simultaneamente culturais e políticas desses 
povos para criar identidades duradouras em contextos gerais de mudança radical e descontinuidade" (1996:1, tradução livre).

Sobre o processo de etnogênese vai nesse sentido também Miguel Bartolomé:

Recuperar uma identificação estigmatizada pela discriminação social não é um processo pessoal ou social simples, isento de conflitos existenciais. Não se trata de um romantismo nostálgico, do qual só se esperam resultados gratificantes, mas da adoção deliberada de uma condição tradicionalmente subalterna, à qual se pretende imprimir uma nova dignidade. Isto pressupõe uma atitude contestatória e de desafio diante da sociedade majoritária em que se gestou o preconceito. Mas também envolve uma capacidade de simbolização compartilhada, por meio da qual antigos símbolos se ressignificam e adquirem o papel de emblemas, capazes de serem assumidos como tais por uma coletividade que encontra neles a possibilidade de construir novos sentidos para a existência individual e coletiva. (2006:57-58, ênfase nossa)

Isso vai ao encontro da perspectiva de Repetto, que encara, no surgimento de novos movimentos culturais, "a cultura como verdadeira arena de luta, onde a orientação dos conflitos está vinculada às orientações culturais e redefinições da mesma" (2008:108).

Os paralelos com as ponderações que até aqui viemos fazendo, em especial no tocante à etnogênese e aos movimentos indígenas como uma crítica não apenas conjuntural, mas a toda uma estrutura de poder é evidente: o surgimento dessa demanda na América do Norte nos diz, segundo penso, bastante sobre a organização das políticas indigenistas no Canadá e Estados Unidos mas, também, sobre como se organizam os movimentos indígenas naqueles países. Tal qual Repetto aponta nas organizações indígenas de Roraima (Repetto, 2008:107), na América do Norte os movimentos indígenas (e, nesse caso específico, o movimento two-spirit) também teriam desenvolvido respostas criativas no sentido de legitimarem seus questionamentos tanto nas arenas governamentais quanto no campo das relações interétnicas. Cria-se, assim, um homossexualismo indígena, ao contrário da situação brasileira, na qual se fala, quando muito, em indígenas homossexuais. No Brasil, ao que tudo indica, o movimento indígena não teria buscado instrumentalizar demandas específicas dos indígenas homossexuais justamente por ser o fenômeno ainda entendido como demanda indi- 
vidual, ligada à opção sexual - e, como vemos, às vezes interpretada como sinal de perda cultural.

Torna-se assim a cultura uma arena de conflitos: os indígenas homossexuais norte-americanos saem da condição de duplamente marginalizados (enquanto indígenas e homossexuais) - inclusive dentro de sua cultura - em busca da legitimação de suas demandas. A forma como fazem isso é paralela àquela pela qual opera a etnogênese: a emergência de uma coletividade distinta, a partir de demandas culturais e políticas, [re]criando identidades e ressignificando símbolos vistos como "tradicionais" (e o próprio conceito de tradição, em si), reposicionando-se diante de sua história.

A resposta criativa dada pelo movimento two-spirit norte-americano foi voltar-se para dentro de si mesmo. O ponto-chave aqui - e foi o que se buscou aqui demonstrar lançando mão do conceito de etnogênese são as condições que tornaram possível a [re]invenção de uma identidade pan-indígena negando-se e afirmando-se ao mesmo tempo, para além de categorias como homossexual e indígena, e superando dicotomias como macho $x$ fêmea, secular $x$ sagrado, indivíduo $x$ coletividade. Mais do que uma "invenção indígena da tradição", ou de uma "tradição indígena da invenção" (cf. Fausto, 2006:28-29), tratar-se-ia, sobretudo, de processos que põem em relação todos esses conceitos, reorganizando-os, bem como desconstroem essas dicotomias, tendo como pano de fundo uma crítica à própria situação colonial.

Em alguma medida, o olhar comparativo entre as realidades brasileira e norte-americana pode nos levar a certo conjunto de questionamentos que merece ser enfrentado de forma mais arguta. Penso que as diferenças entre as situações aqui expostas vão além dos processos de formação dos movimentos indígenas, das políticas indigenistas e das etnologias no Brasil e nos EUA. Nesse sentido, há algumas hipóteses que merecem ser levadas em consideração como fatores explicativos para a diferença entre as realidades encontradas nestas duas situações. Vejamos.

Primeiramente, à exceção do texto de Graciela Chamorro (2009) citado neste artigo, não há, na literatura que alude às práticas homossexuais entre povos indígenas no Brasil qualquer menção a um papel sagrado exercido por essas pessoas em suas culturas. Autores como Baldus (1937); D’Abeville (1945); Gandavo (1858); Gregor (1985); Léry (1941); Magalhães (1876); Métraux (1948); Murphy (1955); Ribeiro (1997), 
Rosário (1839); Sousa (2000); Thevet (1944); Wagley (1977) citam práticas homossexuais observadas entre diferentes povos indígenas no Brasil, sem apontar, contudo, qualquer correlação entre a "sodomia", o "pecado nefando" ou a homossexualidade com um status sagrado dessas pessoas em seus grupos étnicos ${ }^{2}$. Tal omissão pode dever-se a pelo menos três fatores: (a) simplesmente a uma falta de relação direta entre homo/bi/trans/sexualidade, papel social e/ou estatuto ontológico em povos indígenas no Brasil; (b) a uma forma mais rígida de controle sobre as sexualidades indígenas, em primeiro lugar por meio do Poder Pastoral exercido pelos jesuítas ${ }^{3}$, chegando até o Poder Tutelar (Lima, 1995), levado a cabo pelo Serviço de Proteção aos Índios (SPI) e, posteriormente, pela Fundação Nacional do Índio; e (c) tal ausência pode dever-se, ainda, à cegueira epistemológica em torno da temática, uma vez que a noção ocidental de "gênero" não dá conta das perspectivas indígenas de pessoa e de suas implicações sobre as diversas formas de sexualidade indígena.

Em segundo lugar, a formação tanto dos movimentos LGBT quanto indígenas no Brasil e na América do Norte seguiram (e seguem) direções bastante diversas, de forma que o movimento two-spirit deixa gradualmente de se caracterizar como um "movimento social", passando a caracterizar-se como um "grupo social" (Giley, 2006:29), de modo que tem sido cada vez mais frequente os homossexuais não indígenas nos Estados Unidos assumirem-se como two-spirit, apesar da resistência dos indígenas em aceitar isso - Giley (2006), por exemplo, cita a presença de lésbicas veganas nas reuniões two-spirit e o desconforto que isso causa nos indígenas presentes. Tais limites da identidade two-spirit reforçam as diferenciações entre indígenas e não indígenas, mais do que entre heterossexuais e não heterossexuais: nesse sentido vai a aceitação, por parte dos two-spirits entrevistados por mim até aqui ao longo de meu trabalho de campo (realizado nos Estados Unidos entre fevereiro e agosto de 2014), da extensão da ideia de dois espíritos para os indígenas brasileiros e não aos homossexuais, de modo geral. Tal diferenciação se deve basicamente a dois fatores: a assunção de que a identidade two-spirit transcenda a sexualidade, sendo antes uma condição ontológica; além disso, em torno da ideia de two-spirit está, como busquei deixar claro neste texto, uma forte crítica ao colonialismo.

Assim, para entendermos as diferenças entre os dois contextos - brasileiro e norte-americano -, devemos compreender, entre outras coisas, 
que a formação e consolidação do movimento homossexual no Brasil e nos EUA surge no advento da pandemia de AIDS, encontrando, contudo, dois ambientes institucionais bastante distintos: no Brasil, ocorre no contexto de redemocratização do país, sendo em certa medida incorporado na luta contra a doença e se tornando canal na implementação das políticas públicas de prevenção, combate e tratamento; nos Estados Unidos, por outro lado, surge no contexto do governo republicano de Ronald Reagan, de modo que os movimentos LGBT surgem como contraponto ao discurso conservador implementado pelo governo.

No caso brasileiro isso gerou algumas consequências - e o digo à luz da comparação entre entrevistas ${ }^{4}$ com ativistas LGBT do Centro-Sul do país com aqueles da Amazônia Legal: o movimento brasileiro tem sua agenda muito mais voltada para questões localizadas em grandes centros urbanos, bastante atrelada a um discurso branco e de classe média (em que pese a cada vez maior resistência de feministas e ativistas negras na formação de uma agenda própria). Além disso, uma pauta especificamente indígena para questões relativas à homoafetividade perpassaria temas como DST / AIDS e saúde mental, questões sobre as quais o movimento LGBT buscou se desvincular. Com relação aos movimentos indígenas, uma análise detida das agendas nos Estados Unidos e no Brasil certamente merece espaço e aprofundamento os quais não disponho aqui, mas penso ser possível pensarmos em termos de um modelo centrado na ideia de "soberania" e outro, baseado na de "gestão", respectivamente. Assim, a formação do Estado norte-americano fez com que, até a Guerra Civil naquele país, os povos indígenas fossem tratados como Nações, gerando não apenas uma fragmentação nas políticas indigenistas (baseadas em tratados e atos), mas da própria organização indígena, de modo que não há um movimento indígena, pois a própria categoria de indígena é problematizada - não há o "indígena", pois isso seria aceitar as categorias coloniais, havendo em vez disso as nações Cherokee, Navajo, Apache etc. ${ }^{5}$ No Brasil, por outro lado, é frequente a menção não à "soberania" indígena mas à "gestão" indígena - de seu território, de seus recursos naturais, de sua mão de obra etc. Nesse sentido, a discussão em torno das sexualidades indígenas não encontra espaço na agenda indígena brasileira, focada na autonomia de sua gestão, ao contrário das agendas das nações indígenas norte-americanas, centradas na ideia de soberania como contraponto ao colonialismo.

Com relação ao próprio espaço acadêmico para reflexões sobre o tema, não penso que seja necessário destacar aqui as diferenças na produção 
indígena produzida nas academias norte-americana e brasileira - a leitura deste artigo deixa claro o amplo conjunto de textos e reflexões já bastante amadurecidas escritas por autores indígenas norte-americanos. No Brasil, por outro lado, tem-se ainda pela frente o desafio não apenas de se buscar consolidar espaços para a produção dos acadêmicos indígenas, mas sobretudo de se garantir que tais espaços operem a partir de agendas próprias. Dessa maneira, uma agenda em torno de estudos sobre sexualidades indígenas deve não apenas levar em conta a cosmologia e a ontologia dos povos indígenas, mas também os processos e relações de poder a partir dos quais o tema é percebido pelos diversos atores envolvidos - incluindo, evidentemente, a própria comunidade antropológica.

(Recebido para publicação em agosto de 2012)

(Reapresentado em junho de 2014)

(Aprovado para publicação em outubro de 2014) 


\section{Estevão Rafael Fernandes}

\section{NOTAS}

1. Recomenda-se também a leitura dos textos de Goulet (1996) e Epple (1998), para uma discussão pormenorizada das categorias berdache, gay, two-spirit e third gender entre povos indígenas norte-americanos.

2. Para uma análise dessa literatura, ver Fernandes (2013, 2014a, 2014b).

3. Faço aqui uso do conceito de "Poder Pastoral" conforme elaborado por Michel Foucault em seu curso no Collège de France (1977-1978), "Segurança, território e população". Após a leitura e análise da literatura jesuíta produzida nos primeiros séculos de colonização do Brasil, minha hipótese é de que os jesuítas enquadravam a "sodomia" indígena no mesmo conjunto de práticas que incluía a poligamia, a luxúria, a nudez e a antropofagia, tendo como pano de fundo uma visão tomista e aristotélica da natureza e justificada pelas ideias de Ignácio de Loyola de "controle". Espero poder publicar a sistematização dessas ideias em breve, mas a leitura de Eisenberg (2000) e de Jordan (1997) certamente oferece boas possibilidades analíticas sobre a questão.

4. Realizadas entre junho de 2012 e dezembro de 2013.

5. Ver, neste sentido, Shreve (2011); Bruyneel (2007); Cobb e Fowler (2007). 
Ativismo Homossexual Indígena...

\section{REFERÊNCIAS BIBLIOGRÁFICAS}

BAINES, Stephen G. (1997), “Uma Tradição Indígena no Contexto de Grandes Projetos: Os Waimiri-Atroari”. Anuário Antropológico, no 96, pp. 68-81.

BALDUS, Herbert. (1937), Ensaios de Etnologia Brasileira. São Paulo/Rio de Janeiro/Recife, Companhia Editora Nacional.

BARBOSA, Gustavo Baptista. (2004), “A Socialidade contra o Estado: A Antropologia de Pierre Clastres". Revista de Antropologia, vol. 47, no 2, pp. 529-576.

BARTOLOMÉ, Miguel Alberto. (2006), “As Etnogêneses: Velhos Atores e Novos Papéis no Cenário Cultural e Político". Mana, vol. 12, no 1, pp. 39-68.

BRASIL, Kátia. (2008), “Índios Gays São Alvo de Preconceito no Amazonas". Agência Folha, 27/07/2008. Disponível em http://www1.folha.uol.com.br/folha/brasil/ult96u426640.shtml, acesso em julho de 2012.

BRITO, Ivo (org.). (2011), Sexualidade e Saúde Indígenas. Brasília, Paralelo 15.

BROWN, Lester B. (1997), Two-Spirit People: American Indian Lesbian Women and Gay Men. New York, Routledge.

BRUYNEEL, Kevin. (2007), The Third Space of Sovereignty: The Postcolonial Politics of U.S.-Indigenous Relations. Minneapolis, University of Minnesota Press.

CANCELA, Cristina Donza; SILVEIRA, Flávio Leonel Abreu da; MACHADO, Almires. (2010), “Caminhos de uma Pesquisa acerca da Sexualidade em Aldeias Indígenas no Mato Grosso do Sul". Revista de Antropologia, vol. 53, no 1, pp. 199-235.

CHAMORRO, Graciela. (2009), Decir el Cuerpo: Historia y Etnografia del Cuerpo en lós Pueblos Guarani. Asunción, Tiempo de Historia, Fondec.

CANESE, Natalia K. de e ALCARAZ, Feliciano A. (2000), Diccionario Guarani/Español Español/Guarani. Asunción, Instituto Superior de Línguas, Universidad Nacional de Asunción.

CLASTRES, Pierre. (1995), Crônica dos Índios Guayaki: O que Sabem os Aché, Caçadores Nômades do Paraguai. Rio de Janeiro, Ed. 34.

(2003), A Sociedade contra o Estado: Pesquisas de Antropologia Política. São Paulo, Cosac \& Naify.

COBB, Daniel M. e FOWLER, Loretta. (2007), Beyond Red Power: American Indian Politics and Activism since 1900. Santa Fe, NM., School for Advanced Research.

D’ABEVILLE, Claude. (1945), História da Missão dos Padres Capuchinhos na Ilha do Maranhão e Terras Circunvizinhas. São Paulo, Martins Fontes.

DAMATTA, Roberto. (1970), Mito e linguagem social. Rio de Janeiro, Tempo Brasileiro.

DRISKILL, Quo-Li. (2010), “Doubleweaving: Two-Spirit Critiques - Building Alliances between Native and Queer Studies". GLQ: A Journal of Lesbian and Gay Studies, vol. 16, nos 1-2, pp. 69-92.

et al. (eds.). (2011), Queer Indigenous Studies: Critical Interventions in Theory, Politics and Literature. Tucson, The University of Arizona Press.

DADOS - Revista de Ciências Sociais, Rio de Janeiro, vol. 58, nº 1, 2015 


\section{Estevão Rafael Fernandes}

DRISKILL, Qwo-Li et al. (eds.). (2011), Sovereign Erotics: A Collection of Two-Spirit Literature. Tucson, University of Arizona Press.

EISENBERG, José. (2000), As Missões Jesuíticas e o Pensamento Político Moderno: Encontros Culturais, Aventuras Teóricas. Belo Horizonte, Editora UFMG.

EPPLE, Carolyn. (1998), “Coming to Terms into Navajo nádleehí: A Critique of Berdache, 'gay', 'alternate gender' and 'two-spirit'". American Anthropologist, vol. 25, no 2, pp. 267-290.

FAUSTO, Carlos. (2006), “A Indigenização da Mercadoria e suas Armadilhas”, in C. Gordon, Economia Selvagem: Dinheiro, Ritual e Mercadoria entre os Xikrin do Cateté. São Paulo, Unesp.

FERNANDES, Estevão R. (2013), Ativismo Homossexual Indígena e Decolonialidade: Da Teoria Queer às Críticas Two-Spirit. Trabalho apresentado no 37을 Encontro Anual da Anpocs. Águas de Lindoia, SP, 23-27 de setembro.

. (2014a). "Homossexualidades Indígenas y Descolonialidad: Algunas Reflexiones a partir de las Críticas Two-Spirit". Tabula Rasa: Revista de Humanidades, no 20, pp. 135-157.

. (2014b). "Homossexualidade Indígena no Brasil: Desafios de uma Pesquisa". Novos Debates - Fórum de Debates em Antropologia, vol. 1, no 2, pp. 26-33.

GANDAVO, Pero de Magalhães de. (1858), Historia da Provincia de Santa Cruz a que Vulgarmente Chamamos Brasil. Lisboa, Typographia da Academia Real das Sciencias.

GENOVESE, Maddalena e ROUSELL, Davina. (2011), Safe and Caring Schools for TwoSpirit Youth: A Guide for Teachers and Students. Alberta, The Society for Safe and Caring Schools \& Communities. Disponível em http://www.umass.edu/stonewall/uploads/listWidget/25161/TwoSpiritBook.pdf. Acesso em fevereiro de 2015.

GILLEY, Brian Joseph. (2006), Becoming Two-spirit: Gay Identity and Social Acceptance in Indian Country. Lincoln, University of Nebraska Press.

(2010), “Native Sexual Inequalities: American Indian Cultural Conservative Homophobia and the Problem of Tradition". Sexualities, vol. 13, no 1, pp. 47-68.

(2012), "Mark Rifkin. When Did Indians Become Straight? Kinship, the History of Sexuality, and Native Sovereignty (resenha)". The American Historical Review, vol. 117, no 2, pp. 571-572.

GOMES, A. (1956), “Da Homossexualidade ao Dimorfismo Sexual entre os Indígenas e a Questão da Moral Ameríndia". Revista do Instituto Histórico e Geográfico de São Paulo, no 52 , pp. 323-328.

GOULET, Jean-Guy A. (1996), “The 'Berdache' /'Two-Spirit': A Comparison of Anthropological and Native Constructions of Gendered Identities among the Northern Athapaskans". The Journal of the Anthropological Institute, vol. 2, no 4, pp. 683-701.

GREGOR, Thomas. (1985), Anxious Pleasures: The Sexual Lives of an Amazonian People. Chicago, University of Chicago Press.

HILL, Jonathan D. (ed.). (1996), History, Power, and Identity: Ethnogenesis in the Americas, 1492-1992. Iowa, University of Iowa Press. 
Ativismo Homossexual Indígena...

JACOBS, Sue Ellen; THOMAS, Wesley e LANG, Sabine (orgs.). (1997), Two-Spirit People: Native American Gender Identity, Sexuality, and Spirituality. Urbana, University of Illinois Press.

JORDAN, Mark D. (1997), The Invention of Sodomy in Christian Theology. Chicago, University of Chicago Press.

JUSTICE, Daniel Heath; RIFKIN, Mark e SCHNEIDER, Bethany (eds.). (2010), “Sexuality, Nationality, Indigeneity: Rethinking the State at the Intersection of Native American and Queer Studies". GLQ: A Journal of Lesbian and Gay Studies, vol. 16, no 1-2.

LÉRY, Jean de. (1941), Viagem à Terra do Brasil. São Paulo, Livraria Martins.

LIMA, Antônio Carlos de Souza. (1995), Um Grande Cerco de Paz: Poder Tutelar, Indianidade e Formação do Estado no Brasil. Petrópolis, Vozes.

KENSINGER, Kenneth (org.). (1984), "Sexual Ideologies in Lowland South America". Working Papers on South American Indians. Bennington Vermont, Bennington College.

MAGALHÃES, José Vieira Couto de. (1876), “Parte II: Origens, Costumes e Região Selvagem", in O Selvagem. Rio de Janeiro, Typographia da Reforma.

MÉLO, Veríssimo de. (1973), "Relações Sexuais entre os Indígenas Brasileiros", in Ensaios de Antropologia Brasileira. Natal, Imprensa Universitária.

MÉTRAUX, Alfred. (1948), “Ethnography of the Chaco”, in J. H. Steward (ed.), Handbook of South American Indians. Vol 1. Washington, United States Government Printing Office.

MORGENSEN, Scott. (2008), "Becoming Two-Spirit: Gay Identity and Social Acceptance in Indian Country (resenha)". American Ethnologist, vol. 35, no 2, pp. 2077-2080.

(2011), Space between Us: Queer Settler Colonialism and Indigenous Decolonization. Mineapolis, University of Minnesota Press.

MURPHY, Robert e QUAIN, Buell. (1955), The Trumaí Indians of Central Brazil. Seattle/London, University of Washington Press.

REPETTO, Maxim. (2008), Movimentos Indígenas e Conflitos Territoriais no Estado de Roraima. Boa Vista, Editora da UFRR.

RIBEIRO, Darcy. (1997), Confissões. São Paulo, Companhia das Letras.

RIFKIN, Mark. (2011), When did Indians become straight? Kinship, the History, and Native Sovereignty. Oxford, Oxford University Press.

ROSÁRIO, José Manuel. (1839), “História dos Índios Cavalleiros, ou da Nação Guaycurú, Escripta no Real Presídio de Coimbra por Francisco Rodrigues do Prado - Trasladada de um Manuscripto Offerecido ao Instituto pelo Socio Correspondente José Manuel do Rosário". Revista do Instituto Histórico e Geographico do Brazil, Tomo I, no1.

ROSCOE, Will (ed.). (1988), Living the Spirit: A Gay American Indian Anthology. New York, St. Martin's Press.

ROSCOE, Will. (1991), The Zuni-Man-Woman: We'wha and the Zuni Third Gender Role. Albuquerque, University of New Mexico.

. (1995), "Was We'Wha a Homossexual? Native American Survivance and the Two-Spirit Tradition". GLQ: A Journal of Lesbian \& Gay Studies, vol. 2, pp. 193-235.

DADOS - Revista de Ciências Sociais, Rio de Janeiro, vol. 58, nº 1, 2015 


\section{Estevão Rafael Fernandes}

. (1998), Changing Ones: Third and Fourth Genders in Native North America. New York, St. Martin's Press.

SHREVE, Bradley Glenn. (2011), Red Power Rising: The National Indian Youth Council and the Origins of Native Activism. Norman, University of Oklahoma Press.

SOUSA, Gabriel Soares de. (2000), Tratado Descritivo do Brasil em 1587 (edição com comentários feitos por Francisco Adolfo de Varnhagen). Belo Horizonte, Itatiaia.

SPARGO, Tamsim. (2006), Foucault e a Teoria Queer. Rio de Janeiro, Pazulin; Juiz de Fora, EdUFJF.

STOLZE LIMA, Tânia. (2011), "Por uma Cartografia do Poder e da Diferença nas Cosmopolíticas Ameríndias". Revista de Antropologia, vol. 54, no 2, pp. 601-646.

THEVET, André. (1944), Singularidades da França Antarctica: A que Outros Chamam de América. São Paulo, Companhia Editora Nacional.

TREVISAN, João Silvério. (1986), Devassos no Paraíso. A Homossexualidade no Brasil, da Colônia à Atualidade. São Paulo, Max Limonad.

WAGLEY, Charles. (1977), Welcome of Tears. Oxford, Oxford University Press.

WILLIAMS, Walter L. (1992), The Spirit and the Flesh: Sexual Diversity in American Indian Culture. Boston, Beacon Press. 
Ativismo Homossexual Indígena...

\section{RESUMO}

Ativismo Homossexual Indígena: Uma Análise Comparativa entre Brasil e América do Norte

A partir da comparação entre Brasil e América do Norte (principalmente Estados Unidos, mas também, em menor medida, Canadá) este artigo busca compreender a formação e a mobilização do ativismo homossexual indígena nesses dois contextos. O presente trabalho baseou-se em levantamento bibliográfico, entrevistas e trabalho de campo desenvolvido entre junho de 2012 e agosto de 2014. Ao longo do texto será apresentado o percurso recente que levou os Estados Unidos à consolidação do movimento two-spirit, em contraposição à invisibilidade do tema no Brasil. Conclui-se isso se deveu a um conjunto de fatores que fizeram com que os movimentos homossexuais indígenas nos Estados Unidos criassem uma identidade pan-indígena na qual a homossexualidade figura como discurso tradicionalista, religioso e anticolonial, enquanto no Brasil ocorreu o oposto, já que a homossexualidade indígena é vista como "perda" cultural.

Palavras-chave: homossexualidade; movimentos indígenas; gênero; two-spirit, etnologia; teoria queer

\section{ABSTRACT \\ Indigenous Homosexual Activism: A Comparative Analysis between Brazil and North America}

Building upon a comparison between Brazil and North America (mainly the United States, but also Canada) this article seeks to understand the formation and mobilization of homosexual indigenous activism in these two contexts. This research is based on bibliographical studies, interviews and fieldwork carried out between June 2012 and August 2014. The text describes the consolidation of the two-spirit movement in the United States, in contrast to the subjects near invisibility in Brazil. The conclusion is that this was due to a set of factor which allowed homosexual indigenous groups in the United States to create a pan-indigenous identity in which homosexuality figures as a traditionalist, religious and anti-colonial discourse, whereas in Brazil the opposite occurs, since indigenous homosexuality is viewed as a cultural "loss."

Keywords: homosexuality; indigenous movements; gender; two-spirit, ethnology; queer theory

DADOS - Revista de Ciências Sociais, Rio de Janeiro, vol. 58, no 1, 2015 


\section{Estevão Rafael Fernandes}

RÉSUMÉ

Activisme Homosexuel Indigène: Une Analyse Comparative entre le Brésil et l'Amérique du Nord

À partir d'une comparaison entre le Brésil et l'Amérique du Nord (principalement les Etats-Unis, bien que le Canada aussi), cet article cherche à comprendre la formation et la mobilisation de l'activisme homosexuel indigène dans ces deux contextes. Le présent travail s'est basé sur un relevé bibliographique, des entretiens et un travail de terrain mis en œuvre entre juin 2012 et août 2014. Tout au long de cet article seront présentées les évolutions récentes qui ont amené les États-Unis à consolider le mouvement two-spirit, en un contraste évident avec l'invisibilité de la question au Brésil. On en a conclu que cela était le résultat d'un ensemble de facteurs ayant permis la construction, aux États-Unis, d'une identité pan-indigène où l'homosexualité est intégrée au discours traditionnaliste, religieux et anticolonialiste, tandis que le Brésil vit la situation inverse, où l'homosexualité indigène est considérée comme une "perte" culturelle.

Mots-clés: homosexualité; mouvements indigènes; genre; two-spirit; ethnologie; théorie queer

\section{RESUMEN}

Activismo Homosexual Indígena: Un Análisis Comparativo entre Brasil y América del Norte

A partir de una comparación entre Brasil y América del Norte (principalmente Estados Unidos, aunque también, en menor medida, Canadá) este artículo busca comprender la formación y la movilización del activismo homosexual indígena en estos dos contextos. El presente trabajo está basado en discusión bibliográfica, entrevistas y trabajo de campo desarrollado entre junio de 2012 y agosto de 2014. A lo largo del texto se presenta la trayectoria reciente que llevó en Estados Unidos a la consolidación del movimiento two-spirit, en contraste a la invisibilidad del tema en Brasil. Se concluye que esto se debió a un conjunto de factores que llevaron a que los movimientos homosexuales indígenas en Estados Unidos crearan una identidad pan-indígena en la que la homosexualidad aparece como discurso tradicionalista, religioso y anti-colonial, mientras que en Brasil ocurrió lo opuesto, dado que la homosexualidad indígena es vista como "pérdida" cultural.

Palabras clave: homosexualidad; movimientos indígenas; género; two-spirit; etnología; teoría queer. 